\title{
Chemical Characterization and Antioxidant, Antimicrobial, and Insecticidal Properties of Essential Oil from Mentha pulegium L.
}

\author{
Allali Aimad (D), ${ }^{1}$ Rezouki Sanae, ${ }^{1}$ Fadli Anas, ${ }^{1,2}$ El Moussaoui Abdelfattah, ${ }^{3}$ \\ Mohammed Bourhia $\mathbb{D}^{4},{ }^{4}$ Ahmad Mohammad Salamatullah $\left(\mathbb{D},{ }^{5}\right.$ \\ Abdulhakeem Alzahrani $\mathbb{D}^{5}{ }^{5}$ Heba Khalil Alyahya, ${ }^{5}$ Nawal A. Albadr, ${ }^{5}$ Agour Abdelkrim, ${ }^{6}$ \\ Azeddin El Barnossi $\mathbb{D}^{3}{ }^{3}$ and Eloutassi Noureddine ${ }^{7}$ \\ ${ }^{1}$ Laboratory of Animal and Plant Production, and Agro-Industry, Faculty of Sciences, Ibn Tofail University BP 133, \\ Kenitra 14000, Morocco \\ ${ }^{2}$ Southwest Florida Research and Agricultural Center, IFAS, University of Florida, Immokalee, FL 34142, USA \\ ${ }^{3}$ Laboratory of Biotechnology, Environment, Agrifood and Health, Faculty of Science, University of Sidi Mohamed Ben Abdellah, \\ $\mathrm{Fez}$ 30050, Morocco \\ ${ }^{4}$ Laboratory of Chemistry, Biochemistry, Nutrition, and Environment, Faculty of Medicine and Pharmacy, University Hassan II, \\ Casablanca 20000, Morocco \\ ${ }^{5}$ Department of Food Science \& Nutrition, College of Food and Agricultural Sciences, King Saud University, P.O. Box 2460, \\ Riyadh 11451, Saudi Arabia \\ ${ }^{6}$ Laboratory of Natural Substances, Pharmacology, Environment, Modeling, Health \& Quality of Life, Faculty of Sciences, \\ Sidi Mohamed Ben Abdellah University, Fez, Morocco \\ ${ }^{7}$ Regional Center for the Trades of Education and Training (CRMEF), Fez, Morocco
}

Correspondence should be addressed to Allali Aimad; aimad.allali@uit.ac.ma, Mohammed Bourhia; bourhiamohammed@ gmail.com, and Ahmad Mohammad Salamatullah; asalamh@ksu.edu.sa

Received 8 July 2021; Revised 23 September 2021; Accepted 24 September 2021; Published 15 October 2021

Academic Editor: Jorddy Neves Cruz

Copyright (C) 2021 Allali Aimad et al. This is an open access article distributed under the Creative Commons Attribution License, which permits unrestricted use, distribution, and reproduction in any medium, provided the original work is properly cited.

The chemical composition and antibacterial, insecticidal, and antioxidant properties of the essential oil from Mentha pulegium L. (M. pulegium) growing in Morocco were investigated in this work. To achieve this goal, the oils were obtained by using hydrodistillation before being characterized by GC-MS. The antibacterial and antifungal activities were conducted against pathogenic strains using the disc diffusion and MICS bioassays. The insecticidal activity was carried out versus C. maculatus using contact and inhalation tests. The antioxidant activity was performed by using DPPH and total antioxidant capacity bioassays. The chemical analysis of the oil showed that 20 compounds were identified, which represented $98.91 \%$ of the total oil. In the oil, the main components detected were R-(+)-pulegone (76.35\%), carvone (5.84\%), dihydrocarvone (5.09\%), and octanol-3 (2.25\%). The essential oil has moderate-to-strong broad-spectrum antibacterial and antifungal properties; the results showed that $B$. subtilis was the most sensitive strain to $M$. pulegium oil, with the largest inhibition diameter $(25 \pm 0.33)$. For the antifungal activity, the results obtained indicated that Aspergillus niger was the most sensitive fungal strain to M. pulegium oil with an inhibition percentage up to $100 \%$. Regarding the insecticidal activity, the inhalation test showed a high efficacy ( $100 \%$ mortality), and a lethal concentration of $\mathrm{LC}_{50}=1.41+0.48 \mu \mathrm{L} / \mathrm{L}$ air was obtained after 24 hours of exposure. Moreover, the contact test showed that a total reduction in fertility and emergence was obtained with a dose of $20 \mu \mathrm{L} / \mathrm{mL}$ of acetone. Regarding the antioxidant activity, the sample concentration necessary to inhibit 50\% of HE radicals $\left(\mathrm{IC}_{50}\right)$ was $7.659 \mathrm{mg} / \mathrm{mL}(\mathrm{DPPH})$ and $583.06657 .05 \mathrm{mg}$ EAA/g EO (TAC). 


\section{Introduction}

Morocco's geographical location provides a diverse spectrum of bioclimates, allowing for the formation of diverse flora $[1,2]$. The floral wealth is largely related to the ecological heterogeneity of the biotopes. Indeed, it can go from the desert to the high mountains, which allows the development of various species with different bioclimatic stages. The country possesses ancient know-how [3], which has been conserved throughout the ages, in addition to this especially favorable natural setting. In this sense, herbal medicine has witnessed large use by the indigenous people in flavoring and preserving foodstuffs. In Morocco, more than 400 plant species have been accounted for medicinal use [4].

Essential oil (EO) from plants is an important resource of natural products and their components are mainly used as food flavors. Additionally, EO has also non-food applications including antifungal, antimicrobial, antioxidant, and insecticidal activity [5-9]. This confirms the importance of these natural products to develop new alternative solutions in several areas such as health, food safety, and agriculture.

Mentha pulegium L. (M. pulegium) is an indigenous perennial plant found in Europe, North Africa, and the Middle East [10]. Species among Mentha (Labiatae) are widely used against several diseases with a wide spectrum of use, which varies from one region to another. Various research has also revealed that the plant extracts are frequently used as an anti-inflammatory, antispasmodic, carminative, antitussive, diaphoretic, antiemetic, analgesic, stimulant, and emmenagogue and in the form of powders, infusions, and decoctions [11]. The presence of numerous secondary metabolites, including phenolic chemicals, flavonoids, and essential oils, is primarily responsible for these characteristics [12-14].

M. pulegium is an important source of essential oils with pharmacological activities including allelopathic properties [15]. In addition, we found that the essential oil of M. pulegium leaves exhibited significant insecticidal activity against individuals of Oryzaephilus surinamensis, causing a total population reduction at the highest dose [16]. It would be interesting to discover whether $M$. pulegium essential oil and its components have insecticidal properties against other species. As a result, we studied the chemical composition of $M$. pulegium essential oils, as well as their insecticidal activities against Callosobruchus maculatus, one of the most common pests of chickpea grains in Morocco along with antioxidant activity, and antimicrobial activity against some pathogenic strains in this study.

\section{Material and Methods}

2.1. Plant Material and Oil Extraction. M. pulegium was collected from the Moroccan region of Ouazzane $\left(34^{\circ} 47^{\prime} 49 \mathrm{~N},-5^{\circ} 34^{\prime} 56 \mathrm{~W}\right)$. The botanical identification was carried out by a botanist at Sidi Mohamed Ben Abdellah University, where the reference specimen number DM01/ 02501 was deposited. Thereafter, the aerial part of the plant was dried in the shade in a dry and ventilated area of the laboratory at a temperature between 25 and $32^{\circ} \mathrm{C}$. Briefly,
$100 \mathrm{~g}$ of M. pulegium leaves and buds was subjected to essential oil extraction by using hydrodistillation for 3 hours.

2.2. GC-MS of Essential Oils. The identification of the essential oil composition was carried out by gas chromatography-mass spectrometry (GC-MS). Analysis was performed using GC system with a flame ionization detector and an HP-5MS capillary column. Temperature programmed gas chromatography was set to $35^{\circ} \mathrm{C}$ and $250^{\circ} \mathrm{C}$ with a gradient of $5^{\circ} \mathrm{C} / \mathrm{min}$. Gas chromatography with two fused silica capillary columns $(30 \mathrm{~m} 0.25 \mathrm{~mm})$ was used to determine retention indices. The operating temperature was set to 35 and then $250^{\circ} \mathrm{C}$ with a rate of $5^{\circ} \mathrm{C} /$ minutes, alongside lower and upper temperatures held for 3 and 10 minutes, respectively. The carrier gas (helium) flow rate was $1.0 \mathrm{~mL} / \mathrm{min}$. In split mode, a $1.0 \mathrm{~L}$ sample was injected (split ratio, $1: 100$ ). The essential oil constituents were identified by comparing their mass spectra with those of the NIST02 GC/ MS library data and the Adams.

\subsection{Antimicrobial Activity}

2.3.1. Antibacterial Activity. Three filamentous fungi, Aspergillus niger, Aspergillus flavus, and Fusarium oxysporum, and one yeast strain Candida albicans were used in this study for testing. All fungal strains chosen are pathogenic and belong to drug-resistant microbes. They are among the most contaminating microbes of dried vegetables and cereals and the main producers of mycotoxins. Candida albicans is frequently implicated in nosocomial infections. All microbial strains were provided by Sidi Mohamed Ben Abdellah University, Fez, Morocco. Spore suspensions were prepared in a tube containing $0.9 \% \mathrm{NaCl}$ from seven-day-old cultures on a potato dextrose agar (PDA) medium. The number of spores in suspension was counted using a Malassez cell and the suspensions were diluted to obtain an inoculum concentration of approximately $10^{6}$ spores $/ \mathrm{mL}$ [17].

2.3.2. Antibacterial Activity. In this study, the antibacterial activity of $M$. pulegium EO was tested against four bacterial strains including Escherichia coli (ATB: 57) B6N, Staphylococcus aureus, Escherichia coli (ATB: 97) BGM, and $\mathrm{Ba}$ cillus subtilis. All these strains are pathogenic and provided by Hassan II University Hospital Center's Laboratory of Bacteriology in Fez, Morocco. Müller-Hinton Broth (MHB) and Müller-Hinton Agar (MHA) (provided by VWR Chemicals) were used as growth media for bacteria [1]. Isolated colonies from a fresh culture turn $18 \mathrm{~h}$ to $24 \mathrm{~h}$ were transferred to a $0.9 \% \mathrm{NaCl}$ solution to prepare the microbial suspension. Next, the optical density of the suspensions was checked with a UV-Visible spectrophotometer at $625 \mathrm{~nm}$ and adjusted to be between 0.08 and $0.1 \mathrm{~nm}$, which corresponded to suspensions containing a $10^{7}$ to $10^{8} \mathrm{CFU} / \mathrm{mL}$ according to McFarland [18].

2.3.3. Determination of the Inhibition Zone on Solid Mediums. The disc diffusion technique was used to assess the antibacterial and antifungal activities of $M$. pulegium EO 
[19]. Briefly, Petri dishes containing BN (nutrient broth) medium were seeded with the tested bacterial strains (Escherichia coli (ATB: 57) B6N; Escherichia coli (ATB: 97) BGM; Staphylococcus aureus; and Bacillus subtilis) whilst the MEA (Malt Extract Agar) medium was seeded with C. albicans, A. niger, A. flavus, and F. oxysporum. Next, Whatman paper discs $(6 \mathrm{~mm}$ in diameter) were placed on the surface of inoculated culture media after being impregnated with $20 \mu \mathrm{L}$ of EO from $M$. pulegium [20]. After that, the inoculated Petri plates were incubated in the darkness at $30^{\circ} \mathrm{C}$ for fungal strains and $37^{\circ} \mathrm{C}$ for bacterial strains, respectively. After 24 hours of incubation for bacterial strains and 48 hours for C. albicans, inhibitory diameter and percent inhibition were assessed. After 7 days of incubation, the inhibition diameter and percent inhibition of A. niger, A. flavus, and F. oxysporum were determined $[21,22]$.

In this study, the negative control was $10 \mu \mathrm{L}$ of $0.2 \%$ agar, whilst fluconazole was used as a positive control with $5 \mathrm{mg} /$ $\mathrm{mL}$ in the presence of fungal strains, and streptomycin $(0.02 \mathrm{mg} / \mathrm{disc})$ was used as a positive control in the presence of bacterial strains [23].

\subsubsection{Determination of Minimum Inhibitory Concentration} in the Liquid Medium. The microdilution method was used to determine the lowest inhibitory concentration of M. pulegium essential oils against bacterial and fungal strains, according to the method reported by [24]. After 18 hours of incubation for bacteria, 48 hours for yeast, and 7 days for fungi at $30^{\circ} \mathrm{C}[24,25]$, the MIC was determined by using the colorimetric method (TTC $0.2 \%(w / v)$ ) $[25,26]$.

\subsection{Insecticidal Activity}

2.4.1. Insect Rearing. The chickpea pest Callosobruchus maculatus (C. maculatus) was used for insecticidal activity testing. This species was maintained by mass rearing at the laboratory LGME, Department of Chemistry, USMBA, Fez, Morocco. Rearing of C. maculatus bruchid was carried out in glass jars with Cicer arietinum chickpea seeds. For numerous generations, the jars were kept at a constant temperature of $25^{\circ} \mathrm{C}$, relative humidity, and a photoperiod of $14 \mathrm{~h}$ (light)/ 10 h (dark).

\subsubsection{Toxicity of Essential Oil against C. maculatus}

(1) Assessment of Essential Oil Toxicity by Contact. Several preliminary tests were conducted to determine the best doses for testing. Afterward, four doses were prepared by dilution including $0.016,0.079,0.157$, and $0.315 \mu \mathrm{L} / \mathrm{cm}^{2}$, respectively. Filter paper disks with $9 \mathrm{~cm}$ diameter $\left(63.62 \mathrm{~cm}^{2}\right.$ ) (Whatman No. 1) were impregnated into EO before being placed in a glass Petri dish of the same diameter, which served to contain the insect. Only acetone was used to treat the disk for the control. In each Petri dish containing $20 \mathrm{~g}$ of seeds and a treated washer, a batch of 10 adult insects ( 5 males and 5 females) were introduced, freshly collected from their rearing environment and no more than 24 hours old (after emergence from seeds). The dishes were then immediately resealed. For each dose, three replicates were used, and dead insects were counted every 24 hours for four days.

In order to calculate the mortality rate, the number of dead insects was counted each day after the experiment ended. Eggs deposited on the walls of boxes and seeds were counted with a binocular loupe to demonstrate the importance of oviposition. The number of eggs of the treated insect was compared to that of the control. The rate of reduction of oviposition was also calculated [26-30].

(2) Toxicity of EO by Inhalation. Briefly, a small amount of the cotton was suspended into glass jars. Next, doses of $1 \mu \mathrm{L}$, $5 \mu \mathrm{L}, 10 \mu \mathrm{L}$, and $20 \mu \mathrm{L}$ of $M$. pulegium essential oil were deposited into the cotton using a micropipette. Afterward, ten bruchids of $C$. maculatus (male and female) whose ages ranged from 0 and $48 \mathrm{~h}$ were placed in each jar and then closed tightly. For each dose, three replications were carried out. The comparison was made with a control sample (cotton without test solutions).

2.4.3. Calculation Methods. The observed mortality rate was corrected by the following formula:

$$
P c=100 \times \frac{P o-P t}{100-P t},
$$

where $P c=$ percent corrected mortality, $P o=$ observed mortality in the trial, and $P t=$ observed mortality in the control.

The following formula was used to calculate the egglaying reduction rate:

$$
T x=100 \times \frac{N t-N e}{N t},
$$

where $T x=$ rate of reduction relative to the control, $N t=$ number of eggs in the control jar, and $N e=$ number of eggs in the trial.

\subsection{Antioxidant Activity}

2.5.1. Scavenging of the Free Radical DPPH. In the present study, the protocol used was that described by [31]. Briefly, $0.5 \mathrm{~mL}$ of different concentrations of methanol was used to prepare $0.004 \%$ DPPH solution. The reaction mixture was stirred immediately before being kept at room temperature $\left(25^{\circ} \mathrm{C}\right)$ for 30 minutes in the dark. The absorbance of the reaction medium was measured at $517 \mathrm{~nm}$ against a blank containing only methanol. After then, the absorbance was measured and the ascorbic acid was used as a reference. The proportion of DPPH free radical inhibition was estimated using the following method:

$$
\text { \%inhibition }=\frac{\text { Abs control }- \text { Abs sample }}{\text { Abs control }} \times 100 \text {, }
$$

where Abs control is control absorbance (including all reagents except the test substance) and Abs sample is 
absorbance of the test compound. The percentage of inhibition was used to calculate the value of $\mathrm{IC}_{50}$.

2.5.2. Total Antioxidant Capacity Determination. Three hundred microliters of selected doses of EO was mixed with $3 \mathrm{~mL}$ of liquid reactive solution constituted of sulphuric acid, ammonium molybdate, and sodium phosphate. The absorbance was measured using a spectrophotometer set at $695 \mathrm{~nm}$ after a 90 -minute incubation period at $95^{\circ} \mathrm{C}$. The negative control was a blank containing 300 methanol, while the positive control was ascorbic acid [32]. The antioxidant potential of the extracts was measured in mg EAA/g essential oil.

2.6. Data Analysis. The results were presented as arithmetic mean values with standard deviation. One-way ANOVA followed by a Tukey test was used to achieve analysis. SPSS version 21.0 was used, and significant values were considered when $P$ was less than 0.05 .

\section{Results and Discussion}

3.1. Extraction Yield and Chemical Composition of Essential Oil. The yield of EO recovered was $2.14 \pm 0.22 \mathrm{~mL} / 100 \mathrm{~g}$ dry matter. The EO was dried with anhydrous sodium sulfate before being stored in a refrigerator at $4^{\circ} \mathrm{C}$ until further use. The results of GC/MS analysis of essential oil extracted from M. pulegium leaves collected from Ouazzane region are presented in Table 1 and Figure 1. The identified compounds are listed according to the elution order of their retention index.

The yield of EO from $M$. pulegium leaves was $2.14 \pm 0.22 \mathrm{~mL} / 100 \mathrm{~g}$. In this mass, 20 compounds were identified, which represented $98.91 \%$ of the total recovered oil. The oil was majority constituted of compounds among R-(+)-pulegone $76.35 \%$, carvone $5.84 \%$, dihydrocarvone 5.09\%, and octanol-3 2.25\% (Figure 2).

The chemical composition of the studied oils shared some similar compounds with other studies like the pulegone compound [15,33-35]. The pulegone was also found in EOs from $M$. pulegium belonging to the Mediterranean countries with different proportions.

M. pulegium indigenous to Tunisia showed pulegone (61.11\%) and isomenthone (17.02\%) [36]. M. pulegium ingenious to Egypt was found to be also rich in pulegone (43.50\%) and piperitone (12.2\%) [37]. Environmental factors, the portion of the plant employed, the age of the plant, the phase of the vegetative cycle, and even genetic factors may all play a role in the chemical composition of our sample when compared to that recorded in similar species from other regions $[38,39]$. The extraction method can also affect the yield and chemical composition of essential oils, and could therefore, explain the differences in bioactivity $[40,41]$.

The different biological activities of $M$. pulegium plants were caused by the majority compounds in the essential oils. Pulegone (Figure 2) is the most distinctive chemical of M. pulegium, and there are also piperitone (B), menthol (C),
TABle 1: Constituents of the essential oil of M. pulegium identified by GC-MS analysis.

\begin{tabular}{lccc}
\hline Compounds & Components & RI & Area (\%) \\
\hline 1 & $\alpha$-Pinene & 937 & 0.69 \\
2 & Cyclohexanone-3-methyl & 952 & 0.37 \\
3 & $\beta$-Pinene & 974 & 0.52 \\
4 & Myrcene & 992 & 0.14 \\
5 & Octanol-3 & 995 & 2.25 \\
6 & D-2-Carene & 1003 & $\operatorname{Tr}$ \\
7 & Limonene & 1030 & 1.41 \\
8 & $p$-Mentha-3.8-diene & 1071 & 1.95 \\
9 & Menthone & 1150 & 0.08 \\
10 & Pinocarvone & 1166 & 1.76 \\
11 & Isomenthol & 1182 & 0.28 \\
12 & Menthol & 1171 & 0.62 \\
13 & Dihydrocarvone & 1193 & 5.09 \\
14 & R-(+)-pulegone & 1236 & 76.35 \\
15 & Carvone & 1240 & 5.84 \\
16 & $\alpha$-Peperitone & 1251 & 0.36 \\
17 & Caryophyllene & 1418 & 0.18 \\
18 & Germacrene D & 1475 & 0.09 \\
19 & $\gamma$-Eudesmol & 1630 & 0.37 \\
20 & $\alpha$-Eudesmol & 1649 & 0.56 \\
Total identified & & & 98.91 \\
\hline
\end{tabular}

menthone (D), and piperitone oxide chemotypes (E) $[42,43]$. Furthermore, the EO often contains a high percentage of oxygenated monoterpenes [37], with these chemicals accounting for more than $60 \%$ of the total oil [44]. These are known by their activities as biopesticides [45] and the principal contributors to M. pulegium EOs' antioxidant activity $[46,47]$.

(R)-(+)-pulegone is a ketone monoterpene that is found in the essential oils of a variety of plants. It has many bioactivities in cells and animals [48, 49]. According to Damião et al. [50], (R)-(+)-pulegone possessed analgesic therapeutic profile. Roy et al. [51] showed that pulegone reduces LPS-induced inflammation by reducing the effects of NF- $\kappa \mathrm{B}$ suggests that pulegone could be used to treat and prevent a variety of inflammatory illnesses. Also, at $40 \mathrm{mM}$, $\mathrm{R}-(+)$-pulegone reduced $R$. dominica and L. serricorne AChE activity by 69.0 percent and 88.0 percent, respectively. Therefore, pulegone can be considered as a good insecticide against these cereal seed pests [52].

3.2. Antimicrobial Activity. The antimicrobial activities of $\mathrm{EO}$ of $M$. pulegium against pathogenic and phytopathogenic microorganisms were investigated in the present research by the disk diffusion method (Figure 3). The results obtained are presented in Table 2.

The results showed that the essential oils of $M$. pulegium had a significant inhibitory effect against the tested bacterial and fungal strains. The results indicated that B. subtilis was the most sensitive strain tested to $M$. pulegium oil with the highest inhibition diameter $(25 \pm 0.33)$. M. pulegium oil also showed strong antibacterial activity against $E$. coli (ATB: 57 ) B6N (10.33 \pm 0.44$)$, E. coli (ATB: 97) BGM (12 \pm 0.66$)$, and $S$. aureus $(13.16 \pm 0.22)$. For the antifungal activity, the essential oils of $M$. pulegium also showed an important activity 


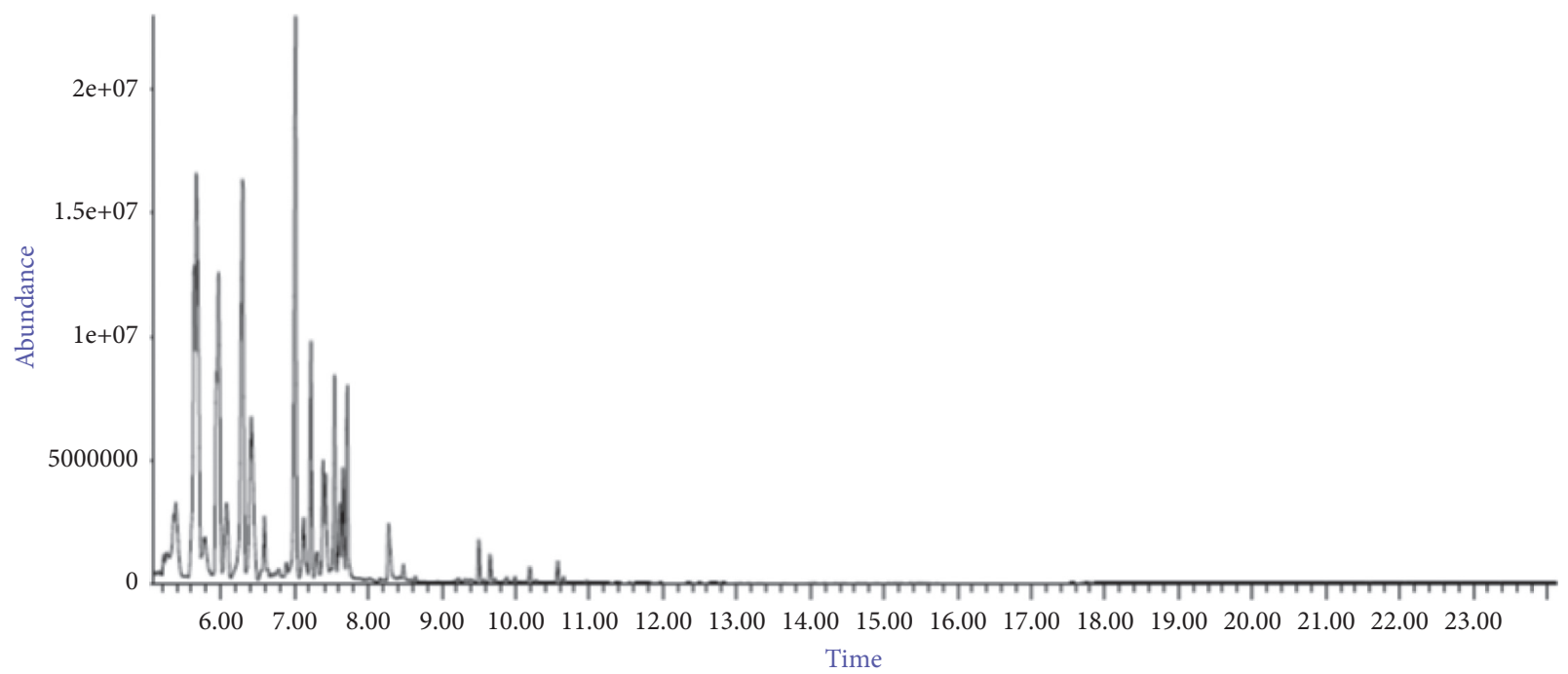

Figure 1: Chromatogram of essential oil from M. pulegium leaves.

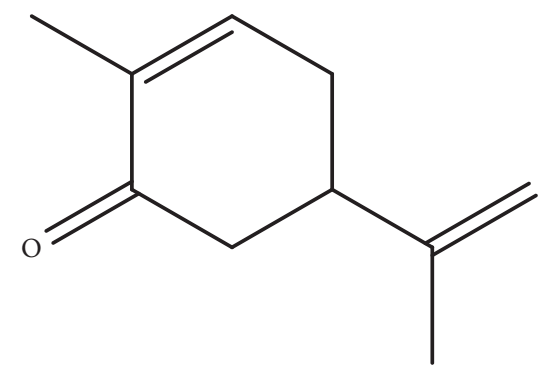

carvone

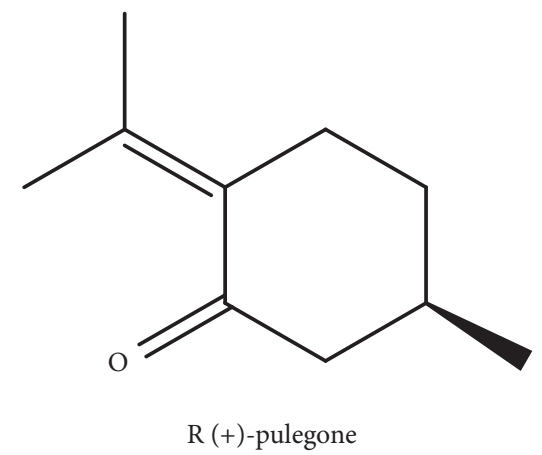

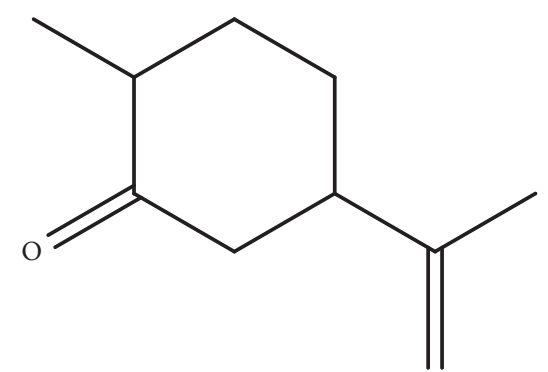

Dihydrocarvone

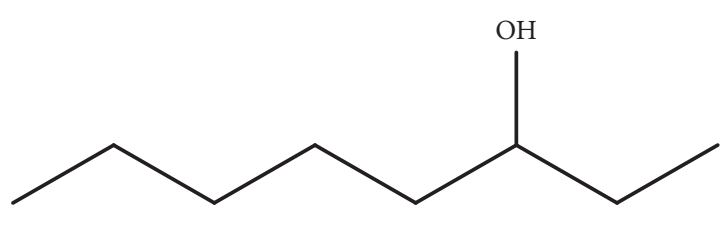

Octanol-3

FIgURE 2: Chemical structure of the main compounds of M. pulegium EO determined by the ChemBioDraw software (Ultra 11.0).

against the tested strains, this activity varied from one strain to another, and the obtained results indicate that Aspergillus niger is the most sensitive fungal strain to the oil of M. pulegium with a percentage of inhibition up to $100 \%$.

Table 3 shows the MIC findings of M. pulegium essential oils against the investigated bacterial and fungal strains. According to the findings, the essential oils of $M$. pulegium have different antibacterial properties. MIC values for bacterial strains (E. coli (TBA: 57) B6N, E. coli (TBA: 97) BGM, Staphylococcus aureus, and Bacillus subtilis) ranged from 0.704 to $2.812 \mathrm{~g} / \mathrm{mL}$. It can therefore be concluded that low doses of $M$. pulegium oil can inhibit bacterial growth of the tested strains. On the other hand, MIC values for fungal strains (A. niger, A. flavus, F. oxysporum, and C. albicans) were between 11.25 and $22.5 \mu \mathrm{g} / \mathrm{mL}$, which means that the fungal strains tested were more resistant than bacterial strains to essential oils. In addition, the oils of M. pulegium showed bactericidal and fungicidal activity against all bacterial and fungal strains tested, respectively. This suggests that the essential oil extracted from $M$. pulegium can be valorized in many fields, especially in food safety thanks to its important antimicrobial activity and its low MIC values against pathogenic and phytopathogenic microorganisms. M. pulegium oil has been given high interest to fight resistant bacteria [53]. The essential oils of M. pulegium from Ouazzane provide antibacterial effects on a wide spectrum of bacterial strains with different MICs (Gram+: S. aureus MBLA: MIC $0.25 \mathrm{mg} / \mathrm{mL}$, S. Aureus 976: CMI $1 \mathrm{mg} / \mathrm{mL}$, 


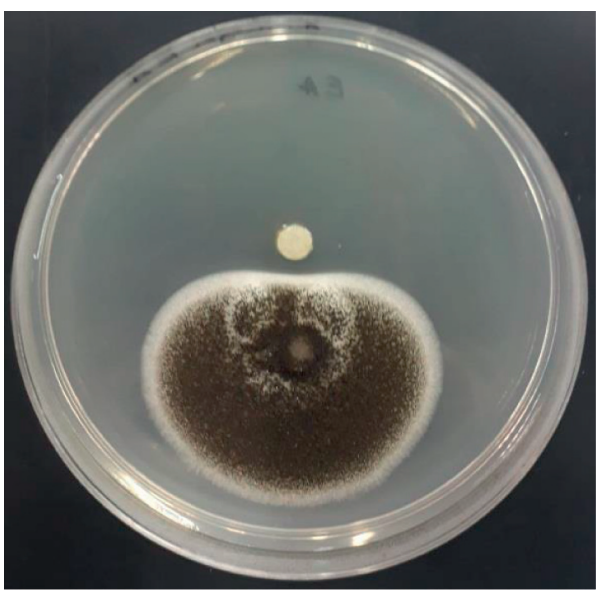

(a)

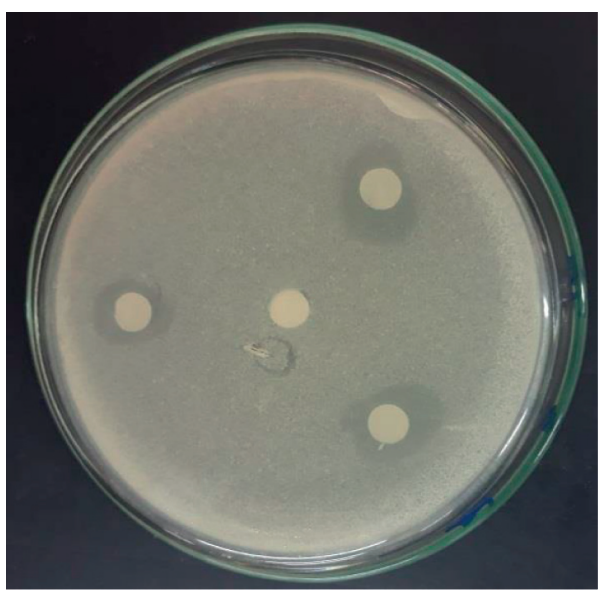

(c)

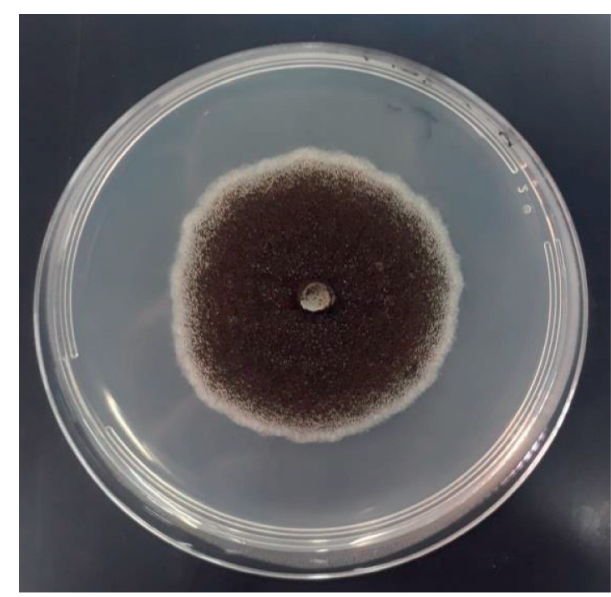

(b)

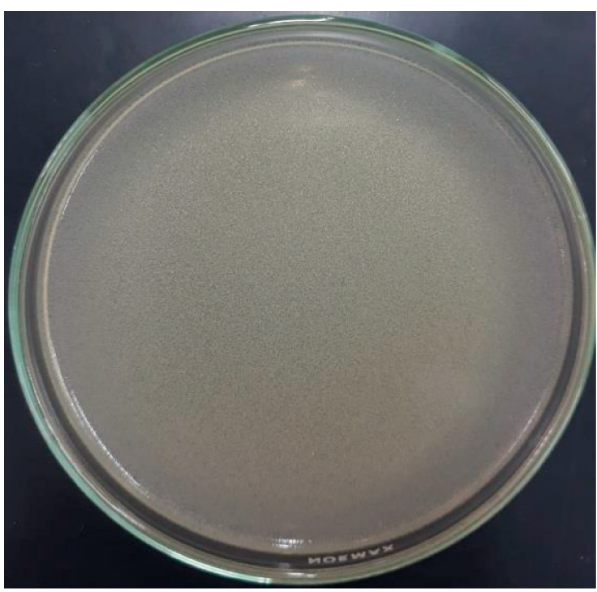

(d)

Figure 3: Pictures showing the antifungal and antibacterial activities of the studied essential oils. (a) Antifungal activity; (b) negative control for antifungal activity; (c) antibacterial activity; (d) negative control for antibacterial activity.

TABle 2: Antibacterial and antifungal effect of Mentha pulegium EOs against bacterial fungal strains.

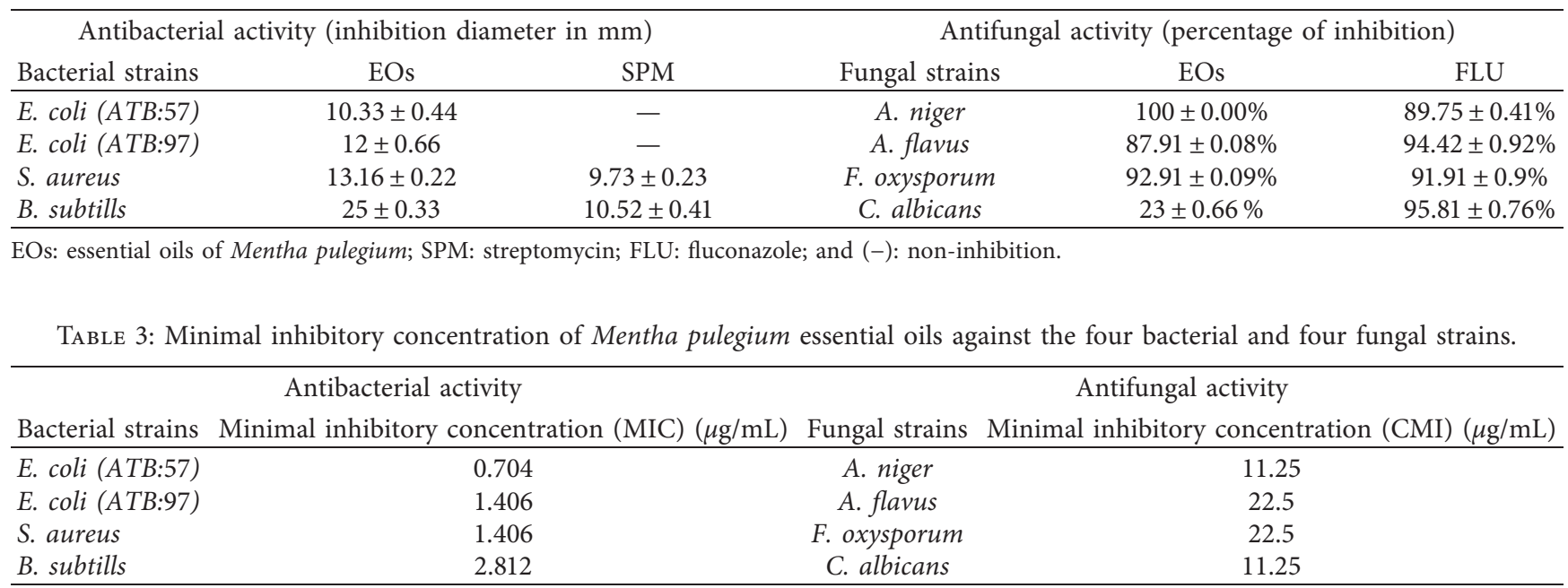


TABle 4: Effects of essential oils of M. pulegium tested by inhalation on the mortality of C. maculatus.

\begin{tabular}{lcccc}
\hline Dose $(\mu \mathrm{m})$ & \multicolumn{3}{c}{ Percentage of mortality per treatment day } \\
& $24 \mathrm{~h}$ & $48 \mathrm{~h}$ & $72 \mathrm{~h}$ & $96 \mathrm{~h}$ \\
\hline Control & $0 \pm 0^{\mathrm{a}}$ & $0 \pm 0^{\mathrm{a}}$ & $0 \pm 0^{\mathrm{a}}$ & $0 \pm 0^{\mathrm{a}}$ \\
1 & $43.3 \pm 4.4^{\mathrm{b}}$ & $63.3 \pm 5.7^{\mathrm{b}}$ & $86.7 \pm 5.7^{\mathrm{b}}$ & $93.3 \pm 11.5^{\mathrm{b}}$ \\
5 & $63.3 \pm 4.4^{\mathrm{c}}$ & $73.3 \pm 5.7^{\mathrm{b}}$ & $100 \pm 0^{\mathrm{c}}$ & $100 \pm 0^{\mathrm{c}}$ \\
10 & $80 \pm 6.6^{\mathrm{d}}$ & $90 \pm 10^{\mathrm{c}}$ & $100 \pm 0^{\mathrm{c}}$ & $100 \pm 0^{\mathrm{c}}$ \\
20 & $100 \pm 0^{\mathrm{e}}$ & $100 \pm 0^{\mathrm{c}}$ & $100 \pm 0^{\mathrm{c}}$ & $100 \pm 0^{\mathrm{c}}$ \\
\hline
\end{tabular}

Columns with the same letter did not differ significantly according to ANOVA analysis.

S. aureus 994: CMI $2 \mathrm{mg} / \mathrm{mL}$, L. monocytogenes: CMI $0.50 \mathrm{mg} / \mathrm{mL}$; Gram-: P. Aeruginosa: CMI $2.00 \mathrm{mg} / \mathrm{mL}, \mathrm{Ba}-$ cillus subtilis: CMI $>2.00 \mathrm{mg} / \mathrm{mL}$, P. mirabilis: CMI $0.50 \mathrm{mg} /$ $\mathrm{mL}$, and Escherichia coli $\mathrm{K} 12$ : CMI $0.50 \mathrm{mg} / \mathrm{mL}$ ) [54]. The essential oils of $M$. pulegium responded differentially to the growth of the bacterial and fungal strains evaluated in our study and elsewhere. In this way, different components may have distinct modes of action, or the metabolism of specific bacteria may be able to counteract the effects of $M$. pulegium oil more effectively. Several studies have shown that the antimicrobial activity of EO can be attributed to its major compounds, such as pulegone (61.10\%), isomenthone (17.00\%), menthone (5.90\%), and piperitone (2.60\%) [33], or to the high concentration of piperitone (38\%) without excluding any potential synergistic effects of constituents [14].

Mentha pulegium possesses antibacterial effects that are effective against a variety of pathogens for hens $[55,56]$. Pulegone, menthone, menthol, and piperitone oxide are responsible compounds for the antibacterial activity of M. pulegium [55, 57], while antifungal activity is attributed to aldehydes, alcohols, and ketones (pulegone, menthone, and neo-menthol) [42]. Yeasts are sensitive to EO from M. pulegium; however, the effect varies depending on the species and strain [58-60].

3.3. Insecticidal Activity. The increasing need for fightstored chickpea pests has led to an interest in the toxicity of plant-derived EOs. In the present work, we tested the essential oil toxicity at different concentrations against C. maculatus for $12,24,48$, and $72 \mathrm{~h}$. We also calculated $\mathrm{LC}_{50}$ values for each $\mathrm{EO}$ concentration at the respective treatment times. In this sense, the toxicity of the essential oils was tested by inhalation (Table 4 ). The $20.0 \mu \mathrm{L} / \mathrm{L}$ air dose showed $100 \%$ efficacy against C. maculatus after $24 \mathrm{~h}$. Meanwhile, the 5 and $10 \mu \mathrm{L} / \mathrm{L}$ air doses killed all pollution after $72 \mathrm{~h}$. Moreover, all oil concentrations showed more than $70 \%$ reduction in oviposition, and more than $90 \%$ emergence (Table 5). A total absence of emergence was recorded in batches treated with 10 and $20 \mu \mathrm{L} / \mathrm{mL}$ of EO (Table 6). Previous studies demonstrated EO from closer plant species tested by inhalation against Sitophilus granarius (L.) weevils (Coleoptera: Curculionidae); generated 100\% mortality after $24 \mathrm{~h}$ of treatment with doses of $5,10,20$, and $40 \mu \mathrm{L} \mathrm{EO} / \mathrm{mL}$ acetone [58].

The contact toxicity test showed lower efficacy when compared to the inhalation test; the $20.0 \mu \mathrm{L} / \mathrm{L}$ dose showed $100 \%$ mortality after $72 \mathrm{~h}$ of exposure. For doses of 5 and
$10 \mu \mathrm{L} / \mathrm{L}$ of air, the total mortality was not achieved until beyond $96 \mathrm{~h}$ of exposure. The lethal dose of the 24-hour inhalation test $\mathrm{LC}_{50}$ was $1.99 \mathrm{~mL} / \mathrm{L}$ air, with a $95 \%$ confidence interval (0.27-4.127) over $48 \mathrm{~h}$ was $0.83 \mathrm{~mL} / \mathrm{L}$ air (Table 7). For the contact test, the $\mathrm{LC}_{50}$ was $6.51 \mathrm{~mL} / \mathrm{L}$ of air over $24 \mathrm{~h}$ of exposure; this value became lower after 48 and $72 \mathrm{~h}$ of exposure (Table 8). It is thus fitting that EOs of M. pulegium tested by inhalation can be a promising source of active compounds to fight chickpea pests. The $20.0 \mathrm{~mL} / \mathrm{L}$ dose was the most active and could be an interesting ecological alternative to eliminate $C$. maculatus from stored seeds.

The insecticidal activity of $M$. pulegium oil has been tested against some insects in previous studies. These studies were mainly classified according to the life stage of the target insect (i.e., adult, larva, and other closer species). Our results showed that $M$. pulegium EOs exhibited efficacy against Callosobruchus maculatus. These results are in agreement with those reported in earlier work $[12,13,15,58,61]$.

The chemical composition of M. pulegium oil, in general, and the monoterpenes that function as insecticidal agents in particular, are responsible for its efficiency [62-64]. Monoterpenes, particularly pulegone, are abundant in our plant (76.35 percent). These active ingredients had significant insecticidal efficacy against a variety of pests $[62,65]$. Pulegone has the ability to enter the lipophilic cuticular tissue layer of insects, resulting in the suppression of respiration, growth, and fecundity. The mechanism of action of the responsible compound can also include the acetylcholinesterase inhibition $[66,67]$. Interference with octamine action, gamma-aminobutyric acid (GABA), modulation of chlorine channels has also been reported in previous works $[68,69]$. In addition, it should be noted that the method of application (inhalation or contact) of $M$. pulegium EO on C. maculatus showed differences in the percentage of mortality, fecundity rate, and emergence rate.

3.4. DPPH Free Radical Scavenging. The DPPH bioassay was used to assess the antiradical activity of $M$. pulegium essential oils. Ascorbic acid (vitamin C) was employed as a standard reference to attain this purpose. Figure 4 depicts the antiradical action of $M$. pulegium essential oil. The essential oils of $M$. pulegium had an $\mathrm{IC}_{50}$ of $7.659 \mathrm{mg} / \mathrm{Ml}$ for antioxidant activity against the DPPH radical. This finding is consistent with prior research, which found that oil from M. pulegium, a native of Iran, had an antioxidant activity with an $\mathrm{IC}_{50}$ of $14736 \mathrm{~g} / \mathrm{mL}$ [11]. When compared to the 
TABLe 5: Effects of essential oils from M. pulegium tested by contact on oviposition and emergence of C. maculatus.

\begin{tabular}{lcc}
\hline Dose $(\mu \mathrm{m})$ & \multicolumn{2}{c}{ Number of eggs and emergence } \\
\hline Number of eggs laid emergence & Number of eggs adults emergence & $0^{\mathrm{a}}$ \\
Control & $0^{\mathrm{a}}$ & $13.67 \pm 2.51^{\mathrm{b}}$ \\
1 & $74.64 \pm 21.2^{\mathrm{b}}$ & $6.33 \pm 1.84^{\mathrm{b}}$ \\
5 & $83 \pm 1.86^{\mathrm{bc}}$ & $100 \pm 0^{\mathrm{b}}$ \\
10 & $98.33 \pm 0.41^{\mathrm{c}}$ & $100 \pm 0^{\mathrm{b}}$ \\
20 & $100 \pm 0^{\mathrm{c}}$ & \\
\hline
\end{tabular}

Columns with the same letter did not differ significantly according to ANOVA analysis.

TABLE 6: Lethal concentration values of $M$. pulegium essential oil tested by inhalation on C. maculatus.

\begin{tabular}{|c|c|c|c|c|c|c|c|}
\hline Treatment $(\mathrm{h})$ & $\mathrm{df}$ & Slope + SD & $\mathrm{LC}_{50}(\mathrm{CI} 95 \%)$ & $\mathrm{LC}_{95}(\mathrm{CI} 95 \%)$ & Intercept $\pm \mathrm{SE}$ & $p$ value & $X^{2}$ \\
\hline 24 & 2 & $1.41+0.48$ & $1.99(0.27 ; 4.127)$ & $28.81(10.93 ; 1900.8)$ & $-0.424+0.382$ & 0.409 & 1.79 \\
\hline 48 & 2 & $1.17+0.51$ & $0.83(0.0 ; 2.298)$ & $20.8(7.03 ; 661438)$ & $0.96+0.379$ & 0.430 & 1.69 \\
\hline 72 & 2 & - & - & - & - & - & \\
\hline 96 & 2 & - & - & - & - & - & - \\
\hline
\end{tabular}

(-): data are absent because the insects died within the first hour of the experiment.

TABLE 7: Effects of essential oils of M. pulegium tested by contact on the mortality of adults from C. maculatus.

\begin{tabular}{lcccc}
\hline \multirow{2}{*}{ Dose $(\mu \mathrm{m})$} & \multicolumn{3}{c}{ Percentage of mortality per treatment day } \\
& $24 \mathrm{~h}$ & $48 \mathrm{~h}$ & $72 \mathrm{~h}$ & $96 \mathrm{~h}$ \\
\hline Control & $0 \pm 0^{\mathrm{a}}$ & $0 \pm 0^{\mathrm{a}}$ & $0 \pm 0^{\mathrm{a}}$ & \\
1 & $16.67 \pm 4.44^{\mathrm{b}}$ & $33.33 \pm 4.44^{\mathrm{b}}$ & $53.33 \pm 4.44^{\mathrm{b}}$ & $70^{\mathrm{a}}$ \\
5 & $26.67 \pm 4.44^{\mathrm{b}}$ & $53.33 \pm 4.44^{\mathrm{c}}$ & $76.67 \pm 4.44^{\mathrm{c}}$ & $90 \pm 0^{\mathrm{b}}$ \\
10 & $60 \pm 6.67^{\mathrm{c}}$ & $73.33 \pm 4.44^{\mathrm{d}}$ & $93.33 \pm 4.44^{\mathrm{d}}$ & $100 \pm 0^{\mathrm{b}}$ \\
20 & $86.67 \pm 4.44^{\mathrm{d}}$ & $96.67 \pm 4.44^{\mathrm{e}}$ & $100 \pm 0^{\mathrm{d}}$ & $100 \pm 0^{\mathrm{b}}$ \\
\hline
\end{tabular}

Columns with the same letter did not differ significantly according to ANOVA analysis.

TABLE 8: Lethal concentration values of M. pulegium essential oil tested by contact on C. maculatus.

\begin{tabular}{|c|c|c|c|c|c|c|c|}
\hline Treatment $(\mathrm{h})$ & $\mathrm{df}$ & Slope + SD & $\mathrm{LC}_{50}(\mathrm{CI} 95 \%)$ & $\mathrm{LC}_{95}(\mathrm{CI} 95 \%)$ & Intercept \pm SE & $p$ value & $X^{2}$ \\
\hline 24 & 2 & $1.56 \pm 0.5$ & $6.51(2.95 ; 15.06)$ & $74.18(25.2 ; 5759.5)$ & $-1.268+0.457$ & 0.004 & 2.01 \\
\hline 48 & 2 & $1.38 \pm 0.51$ & $2.74(0.53 ; 0.69)$ & $42.71(14.9 ; 4580.6)$ & $-0.603+0.389$ & 0.002 & 2.009 \\
\hline 72 & 2 & $1.47 \pm 0.55$ & $1.026(0.032 ; 2.34)$ & $13.43(5.58 ; 806.95)$ & $-0.017 \pm 0.381$ & 0.007 & 0.832 \\
\hline 96 & 2 & - & - & - & - & - & - \\
\hline
\end{tabular}

(-): data is absent because the insects died within the first hour of the experiment.

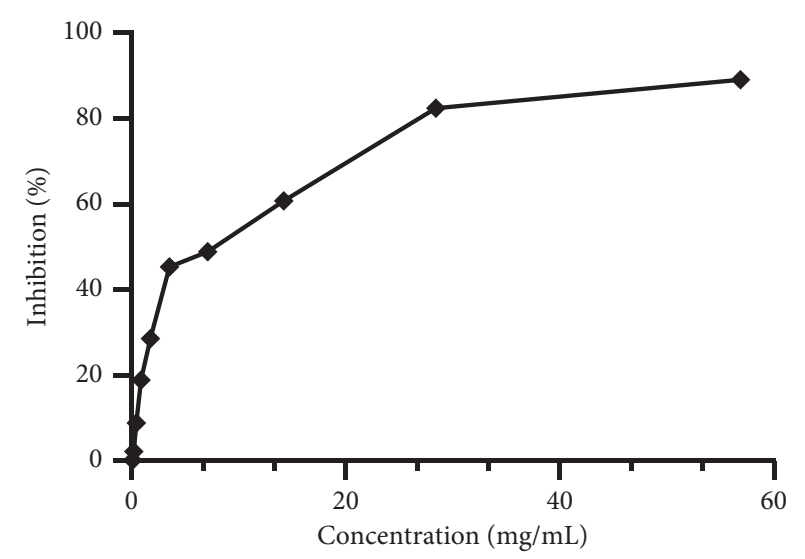

FIGURE 4: Results of the DPPH antioxidant test for Mentha pulegium essential oils.

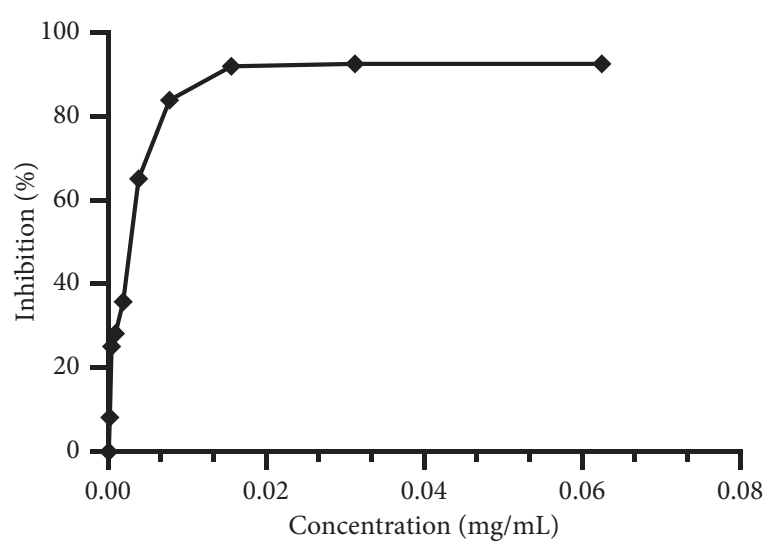

FIgURE 5: Results of the antioxidant test by the DPPH method for ascorbic acid. 
standard synthetic antioxidant (Figure 5), ascorbic acid $\left(\mathrm{IC}_{50}=2.815 \mu \mathrm{g} \mathrm{mL}\right)(\mathrm{P} 0.0001)$, these essential oils have a moderate antioxidant potential. The chemical composition of $M$. pulegium essential oils accounts for their antioxidant action [70]. Pulegone (61.11\%) may be implicated in M. pulegium's antioxidant action [70]. The obtained results are supported by those reported elsewhere, which showed that essential oil from $M$. pulegium from different collection areas had antioxidant power [36].

3.5. Total Antioxidant Capacity (TAC). The measurement of the total antioxidant capacity revealed the presence of important antioxidant agents in the studied oil (583.066 $\pm 57.05 \mathrm{mg} \mathrm{EAA} / \mathrm{g} \mathrm{EO}$ ) (Figure 4). Our results were in agreement with those reported by Ahmed et al. [7], who showed antioxidant activity $\left(\mathrm{IC}_{50}=20.17 \pm 1.88 \mathrm{mg} / \mathrm{mL}\right)$ in essential oils from $M$. pulegium collected from the different collection areas. In addition, the same authors reported that the studied EOs were potent when compared to reference antioxidants, butylated hydroxytoluene (BHT).

Ahmed et al. [7] discovered that the modest variations in components, mainly pulegone and menthone concentrations, can be attributable to the varying degrees of antioxidant capabilities found for EOs isolated from M. pulegium dried by different procedures. In this sense, it was reported that pulegone and menthone identified in M. pulegium may be the responsible compounds for the antioxidant effect $[11,62-73]$.

The active molecules in essential oils of aromatic plants are primarily responsible for their antioxidant properties, according to the literature. The monoterpene ketones menthone and isomenthone are the most powerful molecules [74]. Minor molecules in essential oils, rather than large compounds, are more likely to have a substantial role in antioxidant activity [75]. Similarly, previous works showed the presence of very important antioxidant activity of several essential oils including genus Mentha essential oil [76].

\section{Conclusion}

The chemical composition and antioxidant, antibacterial, and insecticidal activities of $M$. pulegium L. were studied in this work. In conclusion, the essential oil of M. pulegium L. was found to be very rich in R-(+)-pulegone, which remains the main contributor to the biological activities of this oil. This study revealed that the essential oil of M. pulegium was active against the tested microbes, insect pests of legume seeds along with antioxidant effect so that the plant oil can be used as natural drugs to serve health and food crops. Therefore, the essential oil of $M$. pulegium can be exploited in the development of antibiotics, bioinsecticides, and food preservatives. However, on a large-scale practical level, it is necessary to better understand the effect of sublethal doses of essential oils on nontarget organisms, as well as potential toxicities to humans. It is thus fitting that further studies on the potential toxicities of the tested essential oils are needed for safety purposes.

\section{Data Availability}

Data used to support the findings are included within the article.

\section{Conflicts of Interest}

The authors declare that they have no conflicts of interest regarding the publication of this study.

\section{Acknowledgments}

The authors extend their appreciation to the Deanship of Scientific Research at King Saud University for funding this work through research group no. RG-1441-360.

\section{References}

[1] H. Fougrach, W. Badri, and M. Malki, "Flore vasculaire rare et menacée du massif de Tazekka (région de Taza, Maroc)," Bulletin de l'Institut Scientifique, Rabat, Section Science de la Vie, vol. 29, pp. 1-10, 2007.

[2] A. Khabbach, M. Libiad, and A. EnnabilI, "Production et Commercialisation Des Ressources Végétales Dans La Province d," Revue AFN Maroc, vol. 6, pp. 6-8, 2012.

[3] R. Mehdoui and A. Kahouadji, "Abhatoo: etude ethnobotanique auprès de $\mathrm{La}$ population riveraine de $\mathrm{La}$ forêt d'Amsittène: cas de La commune d'Imi n'Tlit (province d'Essaouira)," Bulletin de l'Institut Scientifique, Rabat, Section Science de la Vie, vol. 29, pp. 11-20, 2007.

[4] L. El Rhaffari and A. Zaid, "Pratique de la phytothérapie dans le sud-est du Maroc (Tafilalet): un savoir empirique pour une pharmacopée rénovée," Des sources du savoir aux médicaments du futur, vol. 2002, pp. 293-318, 2002.

[5] F. Bakkali, S. Averbeck, D. Averbeck, and M. Idaomar, "Biological effects of essential oils - a review," Food and Chemical Toxicology, vol. 46, no. 2, pp. 446-475, 2008.

[6] E. J. Christian and A. S. Goggi, "Aromatic plant oils as fungicide for organic corn production," Crop Science, vol. 48, no. 5, pp. 1941-1951, 2008.

[7] A. Ahmed, K. Ayoub, A. J. Chaima, L. Hanaa, and C. Abdelaziz, "Effect of drying methods on yield, chemical composition and bioactivities of essential oil obtained from Moroccan Mentha pulegium L," Biocatalysis and Agricultural Biotechnology, vol. 16, pp. 638-643, 2018.

[8] I. Mssillou, A. Agour, A. El Ghouizi, N. Hamamouch, B. Lyoussi, and E. Derwich, "Chemical composition, antioxidant activity, and antifungal effects of essential oil from laurus nobilis L. Flowers growing in Morocco," Journal of Food Quality, vol. 2020, Article ID 8819311, 8 pages, 2020.

[9] A. Agour, I. Mssillou, H. Saghrouchni, A. Bari, B. Lyoussi, and E. Derwich, "Chemical composition, antioxidant potential and antimicrobial properties of the essential oils of haplophyllum tuberculatum (forsskal) A. Juss from Morocco," Tropical Journal of Natural Product Research, vol. 4, pp. 1108-1115, 2020.

[10] J.-C. Chalchat, M. S. Gorunovic, Z. A. Maksimovic, and S. D. Petrovic, "Essential oil of wild growing Mentha pulegium L. From yugoslavia," Journal of Essential Oil Research, vol. 12, no. 5, pp. 598-600, 2000.

[11] A. Kamkar, A. J. Javan, F. Asadi, and M. Kamalinejad, "The antioxidative effect of Iranian Mentha pulegium extracts and 
essential oil in sunflower oil," Food and Chemical Toxicology, vol. 48, no. 7, pp. 1796-1800, 2010.

[12] A. Kasrati, C. Alaoui Jamali, K. Bekkouche, R. Spooner-Hart, D. Leach, and A. Abbad, "Chemical characterization and insecticidal properties of essential oils from different wild populations ofMentha suaveolenssubsp.timija(Briq.)Harleyfrom Morocco," Chemistry \& Biodiversity, vol. 12, no. 5, pp. 823-831, 2015.

[13] P. Kumar, S. Mishra, A. Malik, and S. Satya, "Insecticidal properties of Mentha species: a review," Industrial Crops and Products, vol. 34, no. 1, pp. 802-817, 2011.

[14] M. Mahboubi and G. Haghi, "Antimicrobial activity and chemical composition of Mentha pulegium L. Essential oil," Journal of Ethnopharmacology, vol. 119, no. 2, pp. 325-327, 2008.

[15] N. Zekri, S. Amalich, A. Boughdad, M. Alaoui El Belghiti, and T. Zair, "Phytochemical study and insecticidal activity of Mentha pulegium L. Oils from Morocco against Sitophilus oryzae," Mediterranean Journal of Chemistry, vol. 2, no. 4, pp. 607-619, 2013.

[16] A. M. Al-Jabr, "Toxicity and repellency of seven plant essential oils to Oryzaephilus surinamensis (Coleoptera: silvanidae) and Tribolium castaneum (Coleoptera: tenebrioidae)," Scientific Journal of King Faisal University, vol. 7, 2006.

[17] H. Moussa, S. Hriouech, M. Tanghort et al., "A comparative study of the antifungal activity of a natural product based on essential oils with imazalil and thiabendazole on Penicillium digitatum and Penicillium italicum," Plant Cell Biotechnology and Molecular Biology, vol. 2020, pp. 16-23, 2020.

[18] J. McFarland, "The nephelometer:an instrument for estimating the number of bacteria in suspensions used for calculating the opsonic index and for vaccines," Journal of the American Medical Association: The Journal of the American Medical Association, vol. XLIX, no. 14, pp. 1176-1178, 1907.

[19] M. Balouiri, M. Sadiki, and S. K. Ibnsouda, "Methods for in vitro evaluating antimicrobial activity: a review," Journal of Pharmaceutical Analysis, vol. 6, no. 2, pp. 71-79, 2016.

[20] A. El Barnossi, F. Moussaid, and A. Iraqi Housseini, "Antifungal activity of Bacillussp. gn-A11-18isolated from decomposing solid green household waste in water and soil against Candida albicans and Aspergillus Niger," E3S Web of Conferences, vol. 150, Article ID 02003, 2020.

[21] A. El Barnossi, F. Moussaid, and A. Iraqi Housseini, "Quantitative research of systematic and functional microbial groups associated with decaying solid green household waste in water and soil," Polish Journal of Environmental Studies, vol. 29, no. 4, pp. 2631-2639, 2020.

[22] J. A. Elegbede, A. Lateef, M. A. Azeez et al., "Silver-gold alloy nanoparticles biofabricated by fungal xylanases exhibited potent biomedical and catalytic activities," Biotechnology Progress, vol. 35, no. 5, Article ID e2829, 2019.

[23] A. EL Moussaoui, M. Bourhia, F. Z. Jawhari et al., "Chemical profiling, antioxidant, and antimicrobial activity against drugresistant microbes of essential oil from withania frutescens L," Applied Sciences, vol. 11, no. 11, p. 5168, 2021.

[24] M. Balouiri, S. Bouhdid, M. Sadiki et al., "Effect of preconditioning cobalt and nickel based dental alloys with Bacillus sp. Extract on their surface physicochemical properties and theoretical prediction of Candida albicans adhesion," Materials Science and Engineering: C, vol. 71, pp. 111-117, 2017.

[25] A. Chebaibi, Z. Marouf, F. Rhazi-Filali, and M. Fahim, A. EdDra, "Évaluation du pouvoir antimicrobien des huiles essentielles de sept plantes médicinales récoltées au Maroc," Phytothérapie, vol. 14, no. 6, pp. 355-362, 2016.

[26] J. Eloff, "A sensitive and quick microplate method to determine the minimal inhibitory concentration of plant extracts for bacteria," Planta Medica, vol. 64, no. 8, pp. 711-713, 1998.

[27] D. Obeng-Ofori, C. Reichmuth, J. Bekele, and A. Hassanali, "Biological activity of 1,8 cineole, a major component of essential oil of Ocimum kenyense (Ayobangira) against stored product beetles," Journal of Applied Entomology, vol. 121, no. 1-5, pp. 237-243, 1997.

[28] P. C. Ojimelukwe and C. Adler, "Potential of zimtaldehyde, 4allyl-anisol, linalool, terpineol and other phytochemicals for the control of the confused flour beetle (Tribolium confusum J. d. V.) (col., tenebrionidae)," Anz. Schadlingskde., Pflanzenschutz, Umweltschutz, vol. 72, pp. 81-86, 1999.

[29] A. L. Tapondjou, C. Adler, D. A. Fontem, H. Bouda, and C. Reichmuth, "Bioactivities of cymol and essential oils of cupressus sempervirens and Eucalyptus saligna against Sitophilus zeamais motschulsky and Tribolium confusum du val," Journal of Stored Products Research, vol. 41, no. 1, pp. 91-102, 2005.

[30] A. F. Ndomo, A. L. Tapondjou, F. Tendonkeng, and F. M. Tchouanguep, "Evaluation des propriétés insecticides des feuilles de Callistemon viminalis (Myrtaceae) contre les adultes d'Acanthoscelides obtectus (Say) (Coleoptera; Bruchidae)," Tropicultura, vol. 27, pp. 137-143, 2009.

[31] M. S. Blois, "Antioxidant determinations by the use of a stable free radical," Nature, vol. 181, no. 4617, pp. 1199-1200, 1958.

[32] P. Prieto, M. Pineda, and M. Aguilar, "Spectrophotometric quantitation of antioxidant capacity through the formation of a phosphomolybdenum complex: specific application to the determination of Vitamin E," Analytical Biochemistry, vol. 269, no. 2, pp. 337-341, 1999.

[33] A. Lamiri, S. Lhaloui, B. Benjilali, and M. Berrada, "Insecticidal effects of essential oils against hessian fly, Mayetiola destructor (say)," Field Crops Research, vol. 71, no. 1, pp. 9-15, 2001.

[34] M. Fadli, J. Chevalier, A. Saad, N.-E. Mezrioui, L. Hassani, and J.-M. Pages, "Essential oils from Moroccan plants as potential chemosensitisers restoring antibiotic activity in resistant gram-negative bacteria," International Journal of Antimicrobial Agents, vol. 38, no. 4, pp. 325-330, 2011.

[35] M. Chraibi, A. Farah, S. Lebrazi, O. El Amine, M. Iraqui Houssaini, and K. Fikri-Benbrahim, "Antimycobacterial natural products from Moroccan medicinal plants: chemical composition, bacteriostatic and bactericidal profile of thymus satureioides and Mentha pulegium essential oils," Asian Pacific Journal of Tropical Biomedicine, vol. 6, no. 10, pp. 836-840, 2016.

[36] H. Hajlaoui, N. Trabelsi, E. Noumi et al., "Biological activities of the essential oils and methanol extract of tow cultivated mint species (Mentha longifolia and Mentha pulegium) used in the Tunisian folkloric medicine," World Journal of Microbiology and Biotechnology, vol. 25, no. 12, pp. 2227-2238, 2009.

[37] A. H. El-Ghorab, "The chemical composition of the Mentha pulegium L. Essential oil from Egypt and its antioxidant activity," Journal of Essential Oil Bearing Plants, vol. 9, no. 2, pp. 183-195, 2006.

[38] D. J. Finney, Probit Analysis, Cambridge University Press, London, UK, 3rd edition, 1972.

[39] R. Karousou, D. N. Koureas, and S. Kokkini, "Essential oil composition is related to the natural habitats: coridothymus 
capitatus and satureja thymbra in NATURA 2000 sites of crete," Phytochemistry, vol. 66, no. 22, pp. 2668-2673, 2005.

[40] S. Rezouki, A. Allali, N. Eloutassi, and M. Fadli, "Biotechnological valorization of aromatic plants in Morocco: impact of extraction methods on the yield and chemical composition of Origanum compactum Benth. of Taounate (Northern Morocco)," Plant Cell Biotechnology and Molecular Biology, vol. 21, pp. 61-62, 2020.

[41] M. S. Oliveira, V. M. P. da Silva, L. C. Freitas, S. G. Silva, J. N. Cruz, and E. H. D. A. Andrade, "Extraction yield, chemical composition, preliminary toxicity of bignonia nocturna (bignoniaceae) essential oil and in silico evaluation of the interaction," Chemistry and Biodiversity, vol. 18, no. 4, 2021.

[42] F. Z. Benomari, V. Andreu, J. Kotarba et al., "Essential oils from Algerian species of Mentha as new bio-control agents against phytopathogen strains," Environmental Science and Pollution Research International, vol. 25, pp. 29889-29900, 2018.

[43] A. C. Kimbaris, A. González-Coloma, M. F. Andrés, V. P. Vidali, M. G. Polissiou, and O. Santana-Méridas, "Biocidal compounds from Mentha sp. Essential oils and their structure-activity relationships," Chemistry and Biodiversity, vol. 14, 2017.

[44] R. A. Oliveira, I. C. G. Sá, L. P. Duarte, and F. F. Oliveira, "Constituintes voláteis de Mentha pulegium L. e Plectranthus amboinicus (Lour.)," Spreng. Revista Brasileira de Plantas Medicinais, vol. 13, pp. 165-169, 2011.

[45] N. G. Ntalli, F. Ferrari, I. Giannakou, and U. MenkissogluSpiroudi, "Phytochemistry and nematicidal activity of the essential oils from 8 Greek lamiaceae aromatic plants and 13 terpene components," Journal of Agricultural and Food Chemistry, vol. 58, pp. 7856-7863, 2010.

[46] B. Nickavar and F. Jabbareh, "Analysis of the essential oil from Mentha pulegium and identification of its antioxidant constituents," Journal of Essential Oil Bearing Plants, vol. 21, pp. 223-229, 2018.

[47] N. Salem, O. Bachrouch, J. Sriti et al., "Fumigant and repellent potentials of ricinus communis and Mentha pulegium essential oils against Tribolium castaneum and lasioderma serricorne," International Journal of Food Properties, vol. 20, pp. S2899-S2913, 2017.

[48] M. Božović, R. Ragno, and N. L. Calamintha, "Savi and its main essential oil constituent pulegone: biological activities and chemistry," Molecules, vol. 22, p. 290, 2017.

[49] T. A. Arruda, R. M. P. Antunes, R. M. R. Catão et al., "preliminary study of the antimicrobial activity of mentha $\mathrm{x}$ villosa hudson essential oil, rotundifolone and its analogues," Revista Brasileira de Farmacognosia, vol. 16, pp. 307-311, 2006.

[50] D. P. d. Sousa, F. F. F. Nóbrega, M. R. V. d. Lima, and R. N. d. Almeida, "Pharmacological activity of (R)(+)-Pulegone, a chemical constituent of essential oils," Zeitschrift für Naturforschung C, vol. 66, no. 7-8, pp. 353-359, 2011.

[51] A. Roy, H.-J. Park, Q. A. Abdul, H. A. Jung, and J. S. Choi, "Pulegone exhibits anti-inflammatory activities through the regulation of NF- $\kappa \mathrm{B}$ and nrf-2 signaling pathways in LPSstimulated RAW 264.7 cells," Natural Product Sciences, vol. 24, no. 1, pp. 28-35, 2018.

[52] G. R. M. Ramadan, S. A. M. Abdelgaleil, M. S. Shawir, A. S. Elbakary, K. Y. Zhu, and T. W. Phillips, "Terpenoids, DEET and short chain fatty acids as toxicants and repellents for Rhyzopertha dominica (coleoptera: bostrichidae) and Lasioderma serricorne (Coleoptera: ptinidae)," Journal of Stored Products Research, vol. 87, Article ID 101610, 2020.

[53] F. Z. El Hassani, "Characterization, activities, and ethnobotanical uses of Mentha species in Morocco," Heliyon, vol. 6, no. 11, Article ID e05480, 2020.

[54] A. Bouyahya, A. Et-Touys, Y. Bakri et al., "Chemical composition of Mentha pulegium and rosmarinus officinalis essential oils and their antileishmanial, antibacterial and antioxidant activities," Microbial Pathogenesis, vol. 111, pp. 41-49, 2017.

[55] H. Oumzil, S. Ghoulami, M. Rhajaoui et al., "Antibacterial and antifungal activity of essential oils of Mentha suaveolens," Phytotherapy Research, vol. 16, no. 8, pp. 727-731, 2002.

[56] S. Saeed and P. Tariq, "Antibacterial activities of Mentha piperita, pisum sativum and momordica charantia," Pakistan Journal of Botany, vol. 37, p. 997, 2005.

[57] G. İşcan, N. Kirïimer, M. Kürkcüoğlu, B. Hüsnü Can, and F. Demirci, "Antimicrobial screening of Mentha piperita essential oils," Journal of Agricultural and Food Chemistry, vol. 50, no. 14, pp. 3943-3946, 2002.

[58] M. Abdelli, H. Moghrani, A. Aboun, and R. Maachi, “Algerian Mentha pulegium L. Leaves essential oil: chemical composition, antimicrobial, insecticidal and antioxidant activities," Industrial Crops and Products, vol. 94, pp. 197-205, 2016.

[59] F. Fancello, S. Zara, G. L. Petretto et al., "Essential oils from three species of Mentha harvested in sardinia: chemical characterization and evaluation of their biological activity," International Journal of Food Properties, vol. 20, pp. 1-11, 2017.

[60] H. Ghazghazi, A. Chedia, M. Weslati et al., "Chemical composition and in vitro antimicrobial activities of Mentha pulegium leaves extracts against foodborne pathogens," Journal of Food Safety, vol. 33, no. 3, pp. 239-246, 2013.

[61] F. Brahmi, A. Abdenour, M. Bruno et al., "Chemical composition and in vitro antimicrobial, insecticidal and antioxidant activities of the essential oils of Mentha pulegium L. And Mentha rotundifolia (L.) huds growing in Algeria," Industrial Crops and Products, vol. 88, pp. 96-105, 2016.

[62] S. A. M. Abdelgaleil, M. I. E. Mohamed, M. E. I. Badawy, and S. A. A. El-arami, "Fumigant and contact toxicities of monoterpenes to Sitophilus oryzae (L.) and Tribolium castaneum (herbst) and their inhibitory effects on acetylcholinesterase activity," Journal of Chemical Ecology, vol. 35, no. 5, pp. 518-525, 2009.

[63] J. M. Herrera, M. P. Zunino, J. S. Dambolena et al., "Terpene ketones as natural insecticides against Sitophilus zeamais," Industrial Crops and Products, vol. 70, pp. 435-442, 2015.

[64] Z. Zhang, T. Yang, Y. Zhang, L. Wang, and Y. Xie, "Fumigant toxicity of monoterpenes against fruitfly, Drosophila melanogaster," Industrial Crops and Products, vol. 81, pp. 147-151, 2016.

[65] G. Franzios, M. Mirotsou, E. Hatziapostolou, J. Kral, Z. G. Scouras, and P. Mavragani-Tsipidou, "Insecticidal and genotoxic activities of mint essential oils," Journal of Agricultural and Food Chemistry, vol. 45, no. 7, pp. 2690-2694, 1997.

[66] J.-H. Park, Y.-J. Jeon, C.-H. Lee, N. Chung, and H.-S. Lee, "Insecticidal toxicities of carvacrol and thymol derived from Thymus vulgaris Lin. against Pochazia shantungensis Chou \& Lu., newly recorded pest," Scientific Reports, vol. 7, no. 1, Article ID 40902, 2017.

[67] F. Tong, A. D. Gross, M. C. Dolan, and J. R. Coats, "The phenolic monoterpenoid carvacrol inhibits the binding of nicotine to the housefly nicotinic acetylcholine receptor," Pest Management Science, vol. 69, no. 7, pp. 775-780, 2013. 
[68] R. S. Rattan, "Mechanism of action of insecticidal secondary metabolites of plant origin," Crop Protection, vol. 29, no. 9, pp. 913-920, 2010.

[69] M. B. Isman, "Botanical insecticides, deterrents, and repellents in modern agriculture and an increasingly regulated world," Annual Review of Entomology, vol. 51, no. 1, pp. 45-66, 2006.

[70] G. Ruberto and M. T. Baratta, "Antioxidant activity of selected essential oil components in two lipid model systems," Food Chemistry, vol. 69, no. 2, pp. 167-174, 2000.

[71] N. Mimica-Dukić, B. Božin, M. Soković, B. Mihajlović, and M. Matavulj, "Antimicrobial and antioxidant activities of ThreeMenthaSpecies essential oils," Planta Medica, vol. 69, no. 5, pp. 413-419, 2003.

[72] B. Teixeira, A. Marques, C. Ramos et al., "European pennyroyal (Mentha pulegium) from Portugal: chemical composition of essential oil and antioxidant and antimicrobial properties of extracts and essential oil," Industrial Crops and Products, vol. 36, no. 1, pp. 81-87, 2012.

[73] A. Kasrati, C. Alaoui Jamali, K. Bekkouche, H. Wohlmuth, D. Leach, and A. Abbad, "Comparative evaluation of antioxidant and insecticidal properties of essential oils from five Moroccan aromatic herbs," Journal of Food Science and Technology, vol. 52, no. 4, pp. 2312-2319, 2015.

[74] D. Yadegarinia, L. Gachkar, M. B. Rezaei, M. Taghizadeh, S. A. Astaneh, and I. Rasooli, "Biochemical activities of Iranian Mentha piperita L. And myrtus communis L. Essential oils," Phytochemistry, vol. 67, no. 12, pp. 1249-1255, 2006.

[75] M.-J. Mukazayire, J. C. Tomani, C. Stévigny et al., "Essential oils of four Rwandese hepatoprotective herbs: gas chromatography-mass spectrometry analysis and antioxidant activities," Food Chemistry, vol. 129, no. 3, pp. 753-760, 2011.

[76] I. J. Borges do Nascimento, N. Cacic, H. M. Abdulazeem et al., "Novel coronavirus infection (COVID-19) in humans: a scoping review and meta-analysis," Journal of Clinical Medicine, vol. 9, no. 4, p. 941, 2020. 